Cahiers $d u$ MONDE RUSSE

\section{Cahiers du monde russe}

Russie - Empire russe - Union soviétique et États indépendants

$52 / 4 \mid 2011$

Varia

\title{
Ilya Vinkovetsky, Russian America
}

\section{Ekaterina Pravilova}

\section{OpenEdition \\ Journals}

\section{Electronic version}

URL: http://journals.openedition.org/monderusse/7590

DOI: 10.4000/monderusse.7590

ISSN: $1777-5388$

\section{Publisher}

Éditions de l'EHESS

\section{Printed version}

Date of publication: 20 December 2011

Number of pages: 696-699

ISBN: 978-2-7132-2353-2

ISSN: $1252-6576$

\section{Electronic reference}

Ekaterina Pravilova, « Ilya Vinkovetsky, Russian America », Cahiers du monde russe [Online], 52/4 | 2011, Online since 28 November 2012, Connection on 23 September 2020. URL : http://

journals.openedition.org/monderusse/7590 ; DOI : https://doi.org/10.4000/monderusse.7590

This text was automatically generated on 23 September 2020

〔c École des hautes études en sciences sociales 


\title{
Ilya Vinkovetsky, Russian America
}

\author{
Ekaterina Pravilova
}

\section{REFERENCES}

Ilya VinKovetSKY, Russian America. An Overseas Colony of a Continental Empire, 1804-1867. New York : Oxford University Press, 2011, 272 p.

1 Russia's colonies in America represented an anomaly within the administrative and economic system of the Russian Empire. The model of a colony run by a semi-private company was borrowed from Russia's maritime rivals, but it did not receive currency outside the American possessions of the Russian crown. The Russian American Company remained a unique example, although the idea of employing private initiatives for the development of remote colonies unreachable by the government and thereby poorly governed, cropped up in the first half of the nineteenth century (the most famous among such projects was Alexander Griboedov's unrealized plan for the creation of a "Russian Transcaucasian Company" (1828)1). The decision to sell Alaska to the United States represented a tacit recognition of the experiment's ultimate fiasco, and was indicative of the peculiarities of Russian imperial policy in the late eighteenthearly nineteenth century. Why did Russia fail to establish itself firmly on the American continent? Although this question might seem to deal more with the problems of geopolitics and Russia's relationship with its rivals, the "interior" factors must be also taken into account. Ilya Vinkovetsky's book offers an "imperial" interpretation of reasons for Russia's abandonment of its American possessions. The book analyzes why and how Russia adopted this form of running a colony, what problems this acquisition incurred (both for those who lived in a colony and in the metropole), and how the experience of running the colony through a private enterprise contributed to the evolution of the Russian imperial system.

2 One of the foundational assumptions of the book is that the model of a colonial company was a British import. On Russian soil, this model underwent a series of changes and adjustments. The Russian version differed from the British template and 
allowed more "rigorous and direct government oversight than its British rival" (69). Vinkovetsky suggests that the greater level of state intrusion was a peculiar feature of Russian colonialism and the Russian pre-reform system of governance, in general. It seems, however, that the conventional (and often not proven) thesis of the Russian state's omnipresence (66) has been uncritically projected upon the administration of the borderlands: in the late eighteenth-early nineteenth century, the Russian authority's presence in its newly acquired territories remained rather meager and unnoticeable. The further away the colony, the more autonomy its local rulers enjoyed. The "privatization" of the borderlands by their administrators was a rather ubiquitous phenomenon at that time, and Vinkovetsky's observation that the Russian American Company, from its creation in 1799, enjoyed remarkable "leeway... in conducting its affairs" (66) points to the similarities rather than anomalies of this case.

The Russian American Company's initial mission was taking the burden of governing the land upon itself in return for the monopoly of extracting resources and the state's rather delusive protection. Hence, one should not overestimate the deliberateness of the early nineteenth century "imperial planners," "Russia's strategists," (13) "designers and implementers of the Russian Empire's colonial policies," (6) who were all responsible for the elaboration of the great "plan" of establishing Russian imperial authority in America. As Russian historian Alexander Petrov asserts, it was initially the entrepreneurs who employed the state for the pursuit of their economic interests, not vice versa. ${ }^{2}$ Indeed, merchants masterfully used the rhetoric of imperial interests while promoting their ideas of strengthening Russia's presence, and securing the state protection for their commercial endeavors: they "persistently urged" the imperial authorities to draw state borderlines in its American possession and furnish merchant ships with signposts indicating Russian's sovereign power over the land. ${ }^{3}$ Indeed, as Vinkovetsky convincingly demonstrates, the beginning of circumnavigation in 1804 and the influx of maritime officers into the governance of the colony enhanced the visibility of the state's presence. However, Vinkovetsky's rigorous statement about the "grand ambitions" nurtured by the government, which used the RAC as an "empirebuilding" tool and the "imperial contractor," (60) contradicts his own portrayal of the vulnerability and the precarious life conditions of the Russian colony populated by less than a thousand of settlers. Vinkovetsky's colorful and impressive description of the Russian settlers' life and their interaction with the indigenous population shows how complex and blurred the power relationships in the colony were - to the extent that the colonizers themselves turned into captives of the sea, their own commercial drive, the will of distant rulers and, to a certain extent, of the people they ruled. Historians have stressed the ambivalent status of Russian colonizers by reversing the narrative and emphasizing the Russians' dependency upon the native population. ${ }^{4}$ Vinkovetsky's account departs from this vision; instead, he describes Russian practices of dominating and imposing the tenets of dependency upon the natives (130-136).

4 As many historians of Russian America before him, Vinkovetsky emphasizes the fact that the decision to abandon the colony was prompted by the emancipation of the peasants. Indeed, in the aftermath of peasant reform, the private company's power over the indigenous people in America evoked unpleasant parallels with serfdom (185). The Russian American Company possessed lands and people while at the same time governing the colony on behalf of the state, thereby exemplifying one of the features of serfdom - the confluence of "dominium" and "imperium," i.e. civil and public power. For the state, the RAC was like a bailiff for an absentee landlord, who enjoyed the 
luxurious life in the capital while paying no attention to the derelict economy of his estate, until the pressure of debts forced him to sell the property. A pre-reform household of a serf village also resembled the one-dimensional colonial economy of Alaska focused on the extensive (and more exhaustive than customary practices of indigenous population) practices of extracting only one kind of resources: fur. Quite characteristically for Russian imperial policy in America, the news about the findings of gold on the continent, close to territory under Russian sovereignty, invoked not hopes but fears, and the feeling of insecurity. Ultimately, this discovery of gold also played a role in the decision to abandon the land..$^{5}$

Minimal infrastructure, trifling investments, and meager income - these were the common features of Russian economic policy, not only in the remote colonies in America (the Minister of Finances Georg Kankrin spoke in the same vein about the Caucasus ${ }^{6}$ ). Vinkovetsky's study offers a nice opportunity (although not sufficiently elaborated in the book) to reflect upon the specificity of imperial policy in the first half of the $19^{\text {th }}$ century. How did the case of Russian America look against the backdrop of other borderlands? The comparison between Russian American possessions and other borderlands occasionally appears in Vinkovetsky's analysis, especially in his fascinating description of the practices of systematizing the population and creating new social categories (the Creoles), the "Russianization" of the natives, and the educational and missionary activity of the Orthodox Church. However, an interpretative study (which is the format of this book) could have claimed bolder and larger comparisons, including the analysis of administrative and political mechanisms and the practices and institutions of colonial rule. In general, it remains unclear how the evolution of the empire and its models of governing borderlands echoed in Russian America. Despite its specificity, the American colony was nevertheless "included" in the transfer of models and practices of colonial rule. ${ }^{7}$ For instance, Vinkovetsky makes the intriguing observation that the form of management through a private company grew more anomalous after the administrative reforms of the 1820s and 1850-60s in the empire (9). Sadly, he has not elaborated on this thought.

6 Vinkovetsky's book makes an important contribution to the study of what he identifies as "myths" and "paradoxes" of Russian overseas colonialism. His book opens up the perspectives for further research into the place Russian America held within the imperial system, and the meaning of this experience for the Russian Empire.

\section{NOTES}

1. Ekaterina Tsimbaeva, «Gosudarstvennyi proekt A.S. Griboedova », Vestnik Moskovskogo Universiteta, Seriia VIII, Istoriia, $\mathrm{n}^{\circ} 2$ (2004): 122-148. On the comparison between the model of the Russian American Company and the projected Russian Transcaucasian Company : ibid.,133.

2. Aleksander Iurievich Petrov, Obrazovanie Rossiisko-Amerikanskoi Kompanii (M : Nauka, 2000), 129.

3. N.N. Bolkhovitinov, ed., Istoriia Russkoi Ameriki, 1732-1867, vol. 1 : Osnovanie Russkoi Ameriki (M : Mezhdunarodnye otnosheniia, 1997), 132. 
4. See, for instance, James Gibson, "Russian Dependence upon the Natives of Alaska ", in S. Frederick Starr, ed., Russia's American Colony (Durham : Duke University Press, 1987), 77-104.

5. Istoriia Russkoi Ameriki, vol. 3: Russkaia Amerika: ot zenita k zakatu (M: Mezhdunarodnye otnoshenia, 1999), 441.

6. See «Mery, predpolagaemye po prisoedinenii Erevanskoi provintsii po chasti Ministerstva Finansov » (1827), RGIA (Rossiiskii Gosudarstvennyi Istoricheskii Arkhiv), f. 561 (Osobennaia kantseliariia ministra finansov), op. 1, d. 30.

7. Note, for instance, how Grigory Shelikhov, the pioneer of commercial exploration and colonial conquest employed the Turkish term 'amanaty' in regard to hostages from natives (Istoriia Russkoi Ameriki, vol. 1, 133). The practices and the vocabulary of domination migrated from other borderlands, as well as (as Vinkovetsky brilliantly shows in his analysis of inventing Russian "creoles") from other empires. 